\title{
Mauri Kiudsoo
}

\section{OTEPÄÄ LINNUSE MÜNDILEID}

On tutvustatud Otepää linnuse hävingukihist 1955. aastal leitud müntide määranguid ja kogu kompleksi varaseimat võimalikku dateeringut. Põgusalt on peatutud ka tollaste leidude maapõue jäämise peamise põhjuse juures.

Mauri Kiudsoo, Tallinna Ülikooli Ajaloo Instituut, Rüütli 6, 10130 Tallinn, Eesti; mauri.kiudsoo@mail.ee

1955. aastal Otepää linnusel toimunud arheoloogiliste kaevamiste käigus avastati ühtekokku 26 münti (AI 4036 ${ }^{1}$ ). Tuginedes nende ajalisele kuuluvusele ja Tallinna Ülikooli Ajaloo Instituudi (edaspidi AI) arheoloogiaarhiivis hoitavale leiuplaanile (AI f 4, n 117, s 114), on alust arvata, et konkreetsed vermingud on algselt moodustanud ühe ning sama leiukompleksi (rahakott või aardeke?). AI numismaatilises kollektsioonis säilitatavad Otepää mündileiu mündid on paraku väga halvasti säilinud, mistõttu nende detailsem määramine on sageli võimatu.

Enim kohtab Otepää leius Tartu piiskopkonna nn vaskseid penne (8 eksemplari), mida on traditsiooniliselt dateeritud piiskop Dietrich III Damerowi valitsemisaja (1379-1400) teise poolde. Samas on täiesti võimalik, et selliseid madalaproovilisi brakteaatpenne valmistati Tartus ka 15. sajandi kahel esimesel aastakümnel (Sarkkinen 2001, 227; Leimus 2005a, 194). Tartu müntidest saab kindlalt 14. sajandisse ajaldada üksnes ühe Dietrich III Damerowi artigi, mis vermiti sealses rahapajas 1395. aastal või ka veidi hiljem. ${ }^{2}$ Seevastu seitse äärmiselt halvasti säilinud Tartu piiskopkonna lübische't võib dateerida pigem 15. sajandisse. Kuigi harrastusnumismaatik Gunnar Haljaku järgi valmistati esimene lübische-tüüp tõenäoliselt juba aastatel 1397-1399(?) (Haljak 2008, 27), seostab Eesti mündiuurija Ivar Leimus oma Tartu mündiajalugu käsitlevas kirjutises nende valmistamise alguse siiski alles piiskop Heinrich Wrangeli (1400-1410) ametiajaga (Leimus 2005a, 194). Tegelikult on Tartu tollane mündiajalugu aga veel üsna ebaselge. Kuna linna keskaegne arhiiv viidi Ivan IV vägede poolt Liivi sõja ajal Moskvasse, kus see arvatavasti Kremli tulekahjus hävis, saab Tartu mündindust uurides toetuda üksnes materiaalsetele allikatele - müntidele ja mündiaaretele (Leimus 2005a, 189).

Kui kahe Otepää leiu mündi määramine on täiesti võimatu ja kolme puhul saab kindlaks teha üksnes nende oletatava nimiväärtuse (lübische), on viit lübische’t võimalik seostada siiski ka Tallinna rahapaja toodanguga (umbes 1390-1420). Viimaste hulgas on kogu kompleksi kõige

1 Alanumbrid: 1289, 1304, 1313-1315, 1317, 1332, 1333, 1337, 1338, 1348, 1349, 1352, 1355, 1357, 1360, 1365, 1375, 1376, 1381, 1383, 1390, 1392, 1393, 1401, 1415.

2 Määrang tugineb Ivar Leimuse veel avaldamata käsikirjas sisalduvale artigite tüpoloogiale. 
hilisem verming (AI 4036: 1401), mis on löödud Liivimaa Ordu poolt ajavahemikul 1406/7(?)-1415 (vt Haljak 2008, tüüp 4, 27). Tuginedes viimati mainitud eksemplari määrangule, on ilmne, et Otepää mündileid ei saanud jääda maapõue enne 1406. aastat.

Küsimusele, kui kaua Otepää leidu kuuluvad mündisordid käibel olid, pole praeguse uurimisseisu juures veel võimalik ammendavat vastust anda. Kuigi aastatel 1422-1426 viidi Liivimaal läbi rahareform (vt Tender 1937, 510-511), mille tõttu käibel olnud mündid ${ }^{3}$ kaotasid(?) kehtivuse, ja ajavahemikul 1363-1420 löödud artigite, seestlingite, lübische’te ning pennide käibimisaja teoreetilise ülempiiri võib seega määratleda võrdlemisi konkreetselt, kohtab käsitletava perioodi mündisorte üksikeksemplaridena isegi veel mõnes 16. sajandi teise ja kolmanda veerandi aardeleius. Enne rahareformi löödud müntide tegeliku käibimisaja kindlakstegemine on raskendatud peaasjalikult just 15. sajandi teise ja kolmanda veerandi aardeleidude minimaalse hulga tõttu (vt lähemalt Kiudsoo 2007, 16, 25). Kuna Otepää linnuselt 1955. aastal avastatud 26 mündi hulgas aga puuduvad rahareformijärgsel ajal löödud vermingud, siis on tõenäoline, et vähemalt leid ise on kokku pandud enne 1426. aastat. $^{4}$

Otepää mündileid (tpq 1406) pärineb Liivimaa keskaja aarderikkaimast perioodist (umbes 1390 1420). Kui näiteks Kalasõjaga (1367-1371) seonduvad leiud on päevavalgele tulnud võrdlemisi piiritletud, otseselt sõjategevuse all kannatanud territooriumilt, siis nüüd katavad aarete leiukohad kogu Liivimaa (vt Leimus 2005b, 81). Need ei saa seotud olla 1390. aastatel toimunud kodusõjaga (Tartu piiskop Dietrich III Damerow versus Liivimaa Ordu), kuna aktiivne sõjategevus toimus üksnes 1396. aastal ja juba 1397 reguleeriti suhted Danzigi lepinguga. Danzigi lepingule järgnes aga üsna rahulik periood (Leimus 2005b, 80). Milles võis siis peituda tollaste aarete maapõue jäämise põhjus? Leimus $(2005 \mathrm{~b}, 81)$ on jõudnud järeldusele, et see oli tingitud sügavast keskaegsest depressioonist, mis kaasnes suure rahvastiku kaotusega. Depressiooniga on seostatav ka 15. sajandi esimese veerandi Liivimaal toimunud kuni kolmekordne hinnatõus (vt Leimus 2005c).

\section{Tänuavaldus}

Käesolev artikkel on valminud Eesti Teadusfondi grandi nr 7680 raames. Autor tänab inglise keele tõlki Liis Soont.

\section{Kasutatud kirjandus}

Haljak, G. 2008. Tallinna ja Tartu lübischete dateerimisest ca 1390-1420. - Räägime asjast. (Varia historica, III.) Eesti Ajaloomuuseum, Tallinn, 16-31.

Kiudsoo, M. 2007. Eesti kesk- ja vara-uusaegsed aardeleiud. Vermingud ja nende ajaline ringlus. Magistritöö. Tartu. Käsikiri TÜ arheoloogia õppetoolis.

Leimus, I. 1999. Tallinna mündiraamatud 1416-1526. (Tallinna Linnaarhiivi toimetised, 3.) Tallinn.

Leimus, I. 2002. Vom Münzgebrauch Livlands, insbesondere in Dorpat in der 2. Hälfte des 14. Jh. The Medieval Town in the Baltic. Toim R. Vissak \& A. Mäesalu. (Hanseatic History and Archaeology, II.) Tartu Linnamuuseum, Tartu, 127-132.

3 14. sajandi lõpul ja 15. sajandi algul olid keskaegsel Liivimaal kasutusel järgmised münditüübid: 1 artig $=3$ lübische $’ \mathrm{t}=6$ seestlingit $=12$ Tartu penni (vt Leimus 2002, 127-132).

4 Otepää leius selgelt domineeriva peenraha valmistamist alustati rahareformi tulemusena taas 1426. aastal, kusjuures algselt kutsusid uued lübische'd ja šerfid, sarnaselt uutele artigitele (killingitele), elanikkonna hulgas esile ägeda vastuseisu (Molvõgin 1969, 59-63; Leimus 1999, 22). 
Leimus, I. 2005a. Mündid. - Tartu ajalugu ja kultuuriajalugu. Toim H. Pullerits, U. Tõnisson, A. Liim \& A. Andresen. Tartu Linnamuuseum, Tartu, 189-196.

Leimus, I. 2005b. Einige Beiträge zur Münzgeschichte Livlands am Ende des 14. Jahrhunderts. Die baltischen Länder und der Norden. Festschrift für Helmut Piirimäe zum 75. Geburtstag. Toim M. Laur \& E. Küng. Akadeemiline Ajalooselts, Tartu, 58-81.

Leimus, I. 2005c. Euroopa hiliskeskaja suur depressioon - kas ka Liivimaal? - Modus vivendi, 2. Toim R. Pullat. (Vana Tallinn, 16 (20)). Estopol, Tallinn, 42-55.

Molvõgin, A. 1969. Über die Münz- und Geldgeschichte Estlands vom Beginn der einheimischen Münzprägung bis zum II. Viertel des 15. Jahrhunderts. - Nordisk Numismatik Årsskrift, 37-65.

Sarkkinen, H. 2001. Einige neue Dorpater Vorreform- und Nachreformkleinmünzen. (Töid ajaloo alalt, 3.) Studia numismatica, II. Festschrift, Mihhail Nemirovitš-Dantšenko 80, Lisa 1. Eesti Ajaloomuuseum, Tallinn, 221-234.

Tender, E. 1937. Müntide ja mõõtude areng Eestis. - Eesti majandusajalugu, I, 501-542.

\section{Mauri Kiudsoo}

\section{COIN FIND FROM THE MEDIEVAL CASTLE OF OTEPÄÄ}

\section{Summary}

In 1955 a coin find was discovered in the destruction layer of the Otepää castle. The largest group of coins ( 8 items) consists of the so-called copper pfennigs of the diocese of Tartu. These are traditionally dated to the second half of the reign of the bishop Dietrich III Damerow (13791400), but it is highly possible that such coins of low silver content were still minted in Tartu during the first two decades of the 15th century. Of the Tartu coins, only an artig of Dietrich III Damerow, minted in 1395 or slightly later, can be dated to the 14th century. On the other hand, seven extremely poorly preserved lübisches of the diocese of Tartu can sooner be dated to the 15th century. Although it cannot be precluded that the first type of lübische was minted already in 1397-1399(?), the beginning of their minting is nowadays connected rather with the tenure of the bishop Heinrich Wrangel (1400-1410). While the identification of two coins from Otepää is utterly impossible, and three coins can be identified only to their presumable denomination (lübische), five lübisches can still be considered as the production of the mint of Tallinn (date to about 1390-1420). The latter include also the latest coin of the complex, minted by the Livonian Order during 1406/7(?)-1415. Relying upon this coin, we may assert that the coin find of Otepää cannot have been deposited before 1406. But since the 26 coins discovered in the castle of Otepää do not include any item minted after the monetary reform, it is likely that the assemblage has been collected at least before 1426 . 